\title{
Ancestral Caddo Sites in the lower Sulphur River Basin at Lake Wright Patman, Bowie and Cass Counties, Texas
}

Timothy K. Perttula

Heritage Research Center, Stephen F. Austin State University

Follow this and additional works at: https://scholarworks.sfasu.edu/ita

Part of the American Material Culture Commons, Archaeological Anthropology Commons, Environmental Studies Commons, Other American Studies Commons, Other Arts and Humanities Commons, Other History of Art, Architecture, and Archaeology Commons, and the United States History Commons

Tell us how this article helped you.

This Article is brought to you for free and open access by the Center for Regional Heritage Research at SFA ScholarWorks. It has been accepted for inclusion in Index of Texas Archaeology: Open Access Gray Literature from the Lone Star State by an authorized editor of SFA ScholarWorks. For more information, please contact cdsscholarworks@sfasu.edu. 


\section{Ancestral Caddo Sites in the lower Sulphur River Basin at Lake Wright Patman, Bowie and Cass Counties, Texas}

\section{Creative Commons License}

\section{(c) (1) \&}

This work is licensed under a Creative Commons Attribution-NonCommercial 4.0 International License 


\title{
Ancestral Caddo Sites in the lower Sulphur River Basin at Lake Wright Patman, Bowie and Cass Counties, Texas
}

\author{
Timothy K. Perttula
}

\section{INTRODUCTION}

The three sites discussed in this article are within the Lake Wright Patman project area on the lower Sulphur River in East Texas (Figure 1). Two of the sites (Clayborn Springs [41BW55] and Mill Creek [41CS125]) are along the existing shoreline and flood pool, but Swen Farm (41BW65) is mostly submerged, except that the crest of the alluvial terrace the site is on is occasionally an island in the lake. All three sites have been eroded by wave action since the creation of Lake Wright Patman in the 1950s, and the Mill Creek site is still being looted (Dockall and Fields 2006:47, 57 and Figure 14).

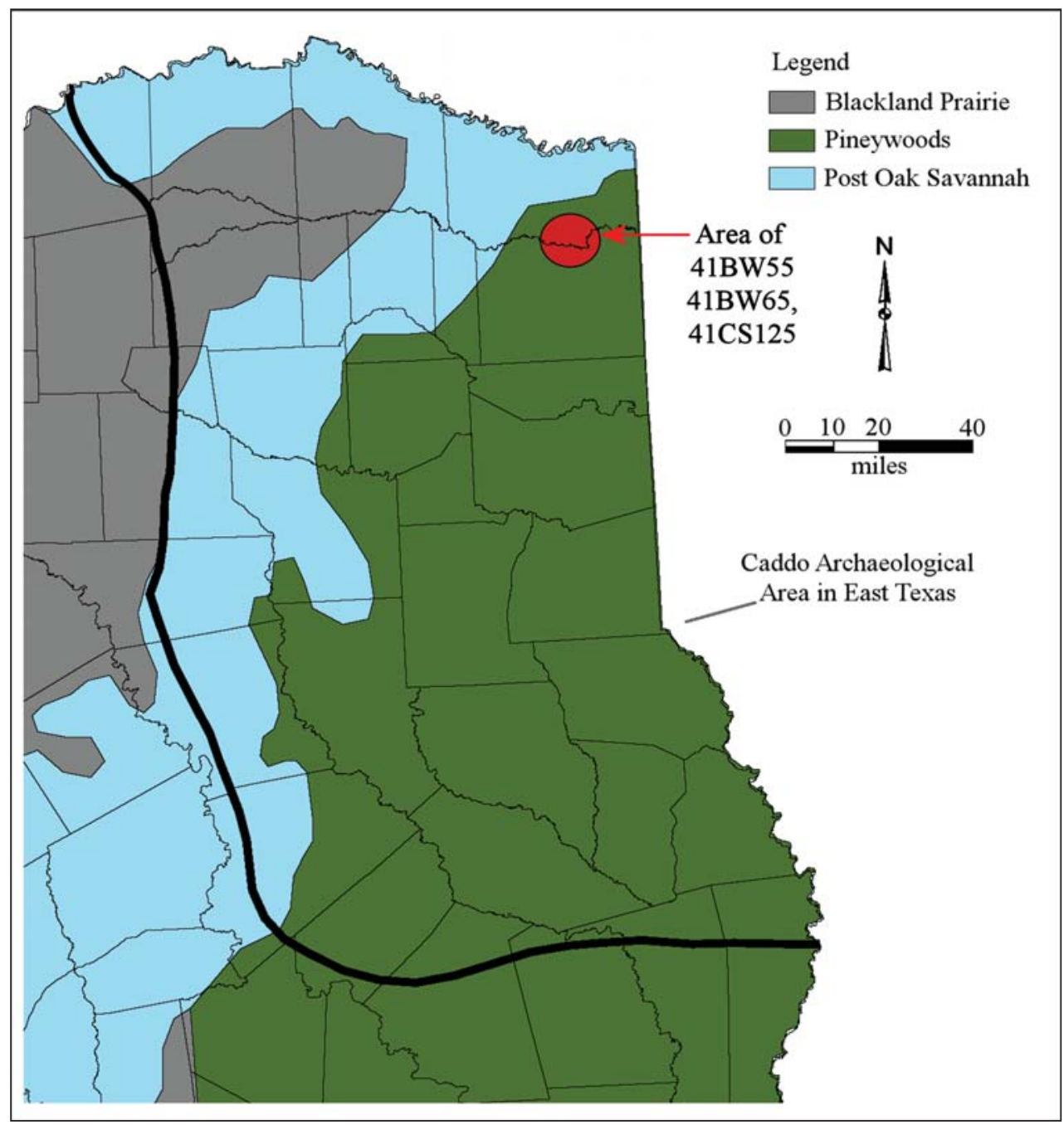

Figure 1. Locations of the Clayborn Springs (41BW55), 41BW65, and Mill Creek (41CS125) sites in the Sulphur River basin in East Texas. 


\section{CLAYBORN SPRINGS SITE (41BW55)}

The Clayborn Springs site is on an alluvial terrace east of Herron Creek, on the north side of the Sulphur River. Briggs and Malone (1970) estimated the site covered a ca. 100-150 m long x 40-50 m wide (ca. 1-2 acres) area of the terrace that had midden deposits as well as looter holes. These holes may have been excavated by several Texarkana collectors some time prior to 1970, including Janson McVay and Paul Schoen, who may have excavated at least eight burials at the site.

The Texas Archeological Research Laboratory at The University of Texas at Austin (TARL) collections from the Clayborn Springs site were obtained by Briggs and Malone (1970). They include two Late Archaic style expanding stem dart points made from novaculite and jasper available in Red River gravels, two arrow point stems (jasper and gray chert), as well as 52 sherds from ceramic vessels. They also noted mussel shell and animal bone at the site, likely preserved in the midden deposits.

The ceramic sherds are from both grog-tempered ( $\mathrm{n}=44,85$ percent) and bone-tempered ( $\mathrm{n}=8,15$ percent) vessels. One rim may be from a relatively thick-walled $(8.5 \mathrm{~mm}$ ) Cooper Boneware vessel (see Schambach 1998), thought to be of Woodland period manufacture in East Texas sites (see Ellis 2013). There are only three decorated sherds in the ceramic assemblage, all from grog-tempered vessels. One is a parallel incised body sherd, another is a Coles Creek Incised, var. Coles Creek rim sherd, dating from ca. A.D. 550-850 (Brown 1998:52), also in the Woodland period in East Texas, and an engraved body sherd from an unidentified Caddo ceramic type with diagonal and sets of curvilinear lines.

\section{SWEN FARM SITE (41BW65)}

This site is on an alluvial terrace on the north and east banks of the Sulphur River. When Briggs and Malone (1970) visited the site, they noted that it had extensive midden deposits up to $1 \mathrm{~m}$ in depth. They also noted that the site was partially submerged, with the top of the terrace forming an island.

Both lithic and ceramic artifacts were collected from the site by Briggs and Malone (1970). The lithic artifacts include 10 dart points and dart point fragments, a quartzitic sandstone celt fragment, and a blade gunflint of non-local gray chert with bifacially trimmed edges. The occurrence of the historic era gunflint, probably of French manufacture, is notable given the discovery of a Historic Caddo burial at the site (see below).

The dart points range from a Late Paleoindian lanceolate stem of a non-local grayish-white chert, four Woodland period Gary and Godley dart points of petrified wood, gray novaculite, and brown jasper, and five fragments (tips, blade, and stem fragments). These dart points are made from gray and white novaculite $(n=3)$, quartzite $(n=1)$, and gray chert $(n=1)$.

The TARL collection from the Swen Farm site has 33 ceramic sherds. This includes 27 plain sherds (among them Williams Plain and Cooper Boneware) and six sherds from utility ware vessels; these vessels are grog-tempered. Three of the sherds have parallel brushing marks, two others have parallel incised lines, and the last decorated sherd has parallel appliqued ridges. This is probably from a Cass Appliqued jar.

In 1974, Larry Head reported to TARL that a burial had been excavated at the Swen Farm site some years earlier that had Caddo ceramic vessels and over 1000 glass beads that date from the early 18th century A.D. This collection of materials from the Swen Farm site, likely from a Nasoni Caddo burial feature (cf. Harris et al. 1980), has unfortunately not been documented to date. 


\section{MILL CREEK SITE (41CS125)}

The Mill Creek site, also known as the Green Farm site or the Island site, is a large ancestral Caddo cemetery on a 5.0 acre alluvial terrace at the mouth of Mill Creek and the east bank of the Sulphur River. Janson McVay, a collector from the Texarkana area, found a Caddo burial washing out at the site in June 1959 , and he and other Texarkana collectors proceeded to excavate 41 burials at the site.

There are no notes or drawings from the various collectors that worked at the Mill Creek site in the records at TARL, but Janson McVay did note in a 1966 letter in the TARL files that he had recovered 46 ceramic vessels, two clay elbow pipes, parts of three long-stemmed Red River pipes, one celt, three bone pins, and nine arrow points, including one Bassett, from the unknown number of burials that he had excavated at the site. The fact that both elbow pipes and long-stemmed Red River styles pipes were among the funerary offerings in the burials, along with one Bassett arrow point, indicates that the burials at the Mill Creek site were interred both before and after ca. A.D. 1400.

McVay also donated sherds from the site to TARL, including 129 plain rim, body, and base sherds and 54 decorated rim and body sherds from utility ware and fine ware sherds (Table 1). About 84 percent of the sherds are from grog-tempered vessels and the remaining 16 percent are from bone-tempered vessels.

Table 1. Ceramic assemblage from the Mill Creek site.

\begin{tabular}{lrrr}
\hline Ware & Grog & Bone & N \\
\hline Plain & 105 & 24 & 129 \\
Utility & 33 & 4 & 37 \\
Fine & 15 & 2 & 17 \\
\hline Totals & 153 & 30 & 183 \\
\hline
\end{tabular}

Almost 70 percent of the decorated sherds $(n=37)$ are from utility ware vessels (Table 2). Many of these have brushed decorations, either as the sole decorative element $(n=12,32$ percent of the utility ware sherds) or in combination with appliqued $(n=2)$, incised $(n=1)$, lip notching $(n=-1)$, or punctated $(n=1)$ elements. These sherds with brushed-other decorative elements comprise another 13.5 percent of the utility ware sherds from the Mill Creek site. These sherds are likely from Pease Brushed-Incised jars. Other common utility ware decorative methods are incised $(n=9,24$ percent of the utility ware sherds), appliqued ( $n=5,13.5$ percent), and neck banded ( $n=2,5.4$ percent). The neck banded sherds are from Nash Neck Banded jars while the appliqued sherds are probably from the bodies of McKinney Plain jars.

Table 2. Decorated sherds from the Mill Creek site.

\begin{tabular}{llll}
\hline $\begin{array}{l}\text { Decorative method/ } \\
\text { Decorative element }\end{array}$ & Grog & Bone & N
\end{tabular}

\section{Appliqued}

straight appliqued fillet

straight appliqued ridge

\section{Brushed}

opposed brushing marks 
Table 2. Decorated sherds from the Mill Creek site, cont.

$\begin{array}{llll}\text { Decorative method/ } & \text { Grog } & \text { Bone } & \text { N } \\ \text { Decorative element }\end{array}$

Decorative element

\section{Brushed-Appliqued}

parallel brushed-straight appliqued fillet

1

parallel brushed-straight appliqued ridge

\section{Brushed-Incised}

parallel brushed-incised

\section{Brushed-Lip Notched}

horizontal brushed on rim; lip notched

\section{Brushed-Punctated}

horizontal brushed-tool punctated rows under

\section{Engraved}

concentric semi-circles

concentric semi-circles and brackets with

negative ovals

curvilinear lines

horizontal lines

horizontal lines and cross-hatched zone

horizontal scroll with hatched zones and

horizontal line with tick marks

horizontal lines and slanting scroll; hatched

triangle element

horizontal and vertical lines

parallel lines

straight line

\section{Incised}

cross-hatched lines

diagonal opposed lines

horizontal line or lines

parallel lines

straight lines

\section{Incised-Appliqued}

vertical and opposed lines and a vertical appliqued ridge
1

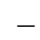

$-$

1

1

1

4

1

1

1

12

12

1

1

3

$\begin{array}{ll}- & 1\end{array}$

$\begin{array}{ll}- & 4\end{array}$

$\begin{array}{ll}- & 1\end{array}$

$\begin{array}{ll}- & 1\end{array}$

1

12

$\begin{array}{ll}1 & 3 \\ - & \end{array}$ 
Table 2. Decorated sherds from the Mill Creek site, cont.

\begin{tabular}{lccc}
\hline $\begin{array}{l}\text { Decorative method/ } \\
\text { Decorative element }\end{array}$ & Grog & Bone & N \\
\hline $\begin{array}{l}\text { Incised-Punctated } \\
\text { parallel lines and adjacent tool punctated row }\end{array}$ & 1 & - & 1 \\
$\begin{array}{l}\text { Neck Banded } \\
\text { horizontal neck banding }\end{array}$ & 2 & - & 2 \\
$\begin{array}{l}\text { Punctated } \\
\text { cane punctated rows/zone } \\
\text { circular punctated rows }\end{array}$ & 1 & & \\
\hline \begin{tabular}{l} 
Totals \\
\hline
\end{tabular} & 1 & - & 1 \\
\hline
\end{tabular}

The fine ware sherds from the Mill Creek site all have engraved decorative elements. They include a body sherd from a Hatchel Engraved bottle with oval panels filled with concentric semi-circles; the panels are divided by bracket elements with a series of embedded negative ovals (Figure 2a). Other engraved bottle sherds have curvilinear lines as well as horizontal and vertical lines (Figure $2 \mathrm{~g}$ ). The remainder of the engraved sherds from the Mill Creek site are from carinated bowls (Figure 2b-f).

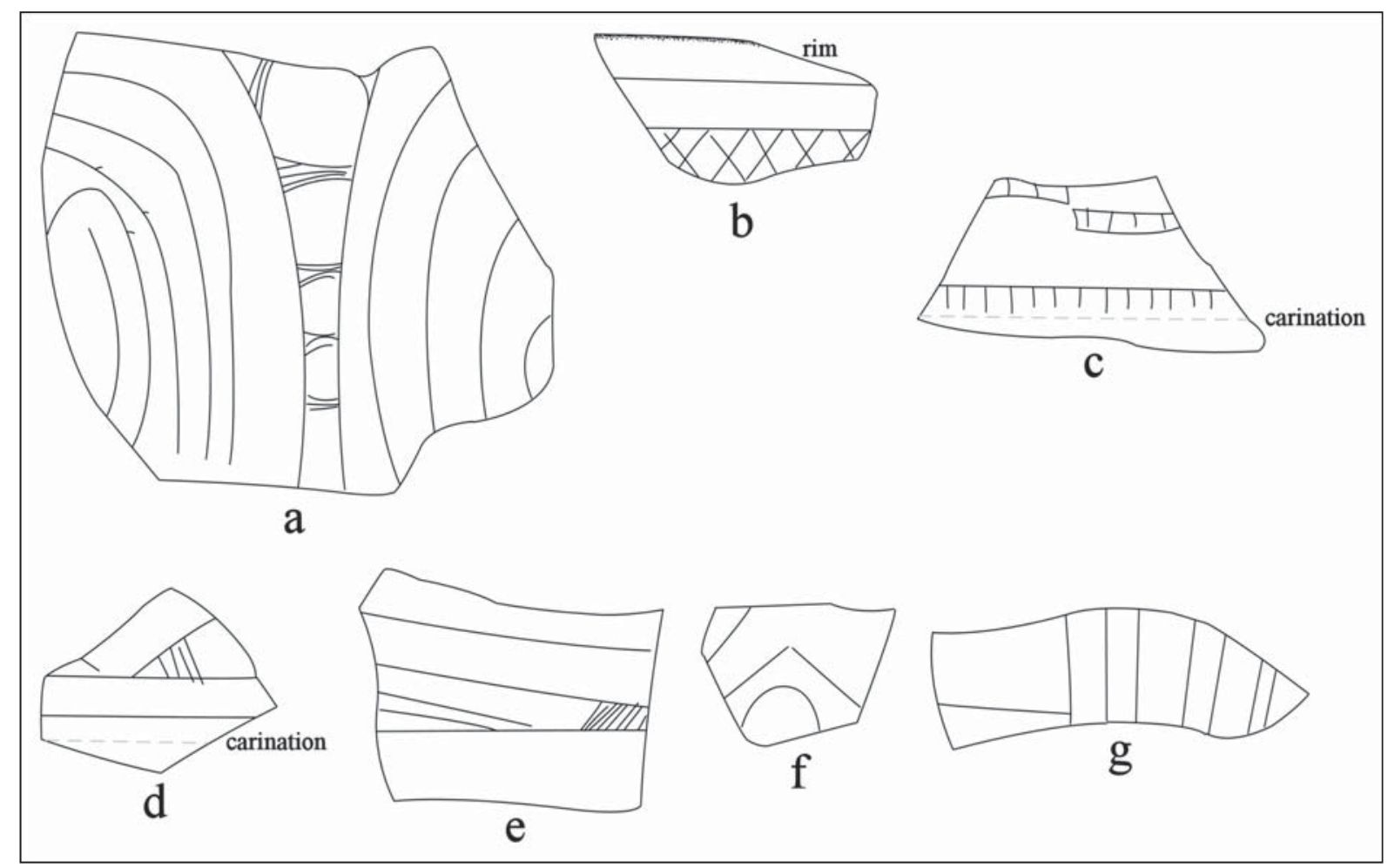

Figure 2. Selected decorative elements in fine ware sherds from the Mill Creek site: a, Hatchel Engraved bottle sherd; b-f, engraved carinated bowl sherds; g, engraved bottle sherd. 
Among the engraved carinated bowl sherds is a rim with a cross-hatched zone below two horizontal lines on the panel (see Figure 2b), as well as a Barkman Engraved sherd with a horizontal scroll marked by narrow hatched zones, as well as a ticked horizontal line above the carination (see Figure 2c). Two other sherds have slanting scroll motifs with excised or hatched triangle elements (see Figure 2d-e), while another has a concentric semi-circle element (see Figure 2f).

\section{SUMMARY AND CONCLUSIONS}

The three ancestral Caddo sites discussed in this article are on alluvial terraces in the lower Sulphur River valley at Lake Wright Patman in East Texas. All three of the sites are reported to have Caddo burials, as many as 41 burial features at the Mill Creek site, and the Clayborn Springs and Swen Farm sites also have substantial (but eroded and looted) midden deposits. The principal Caddo occupations at the Swen Farm and Mill Creek sites appears to have been during the early part of the Late Caddo period (ca. A.D. 1400-1550) - based on the proportion of brushed utility wares as well as the occurrence of defined types such as Barkman Engraved, Cass Appliqued, Hatchel Engraved, McKinney Plain, Nash Neck Banded, and Pease Brushed-Incised. In addition to a blade gunflint, an early 18th century Caddo burial has also been excavated at the Swen Farm site, and it is known that at least 1000 European glass beads were among the funerary offerings with this burial. This is one of only a few historic Nasoni Caddo burial features known on the lower Sulphur River in East Texas.

In addition to the Caddo occupations of Late Caddo and Historic Caddo age at the Swen Farm and Mill Creek sites, there is also evidence of use of the alluvial terrace landforms during earlier periods. This includes from as early as the late Paleoindian period at the Clayborn Springs site, but with more substantial usage during the Late Archaic at the Swen Farm site, and during the Woodland period at the Clayborn Springs and Swen Farm sites. These sites have sherds from Williams Plain, Cooper Boneware, and Coles Creek Incised vessels.

\section{ACKNOWLEDGMENTS}

Lance Trask prepared the figures for this article. Jonathan Jarvis at TARL facilitated access to the records and collections from these three sites.

\section{REFERENCES CITED}

Briggs, A. K. and J. Malone

1970 Texarkana Reservoir Enlargement. Archeological Survey Report No. 7. Texas Historical Survey Committee, Austin.

Brown, I. W.

1998 Decorated Pottery of the Lower Mississippi Valley: A Sorting Manual. Mississippi Archaeological Association and Mississippi Department of Archives and History, Jackson.

Dockall, J. E. and R. C. Fields

2006 Reconnaissance Survey to Assess the Impacts on Archeological Resources of the Proposed Conservation Pool Level Raise at Wright Patman Lake, Bowie and Cass Counties, Texas. Reports of Investigations No. 146. Prewitt and Associates, Inc., Austin.

Ellis, L. W.

2013 Woodland Ceramics in East Texas and a Case Study of Mill Creek Culture Ceramics. Bulletin of the Texas Archeological Society 84:137-180. 
Harris, R. K., I. M. Harris, and P. Miroir

1980 The Atlanta State Park Site in Northeastern Texas. Louisiana Archaeology 6:231-239.

Schambach, F. F.

1998 Pre-Caddoan Cultures of the Trans-Mississippi South. Research Series 53. Arkansas Archeological Survey, Fayetteville. 